The Europeanization of Welfare - The Domestic Impact of Intra-European Social Security

Martinsen, Dorte Sindbjerg

Published in:

Journal of Common Market Studies

DOI:

doi:10.1111/j.1468-5965.2005.00607.x

Publication date:

2005

Document version

Early version, also known as pre-print

Citation for published version (APA):

Martinsen, D. S. (2005). The Europeanization of Welfare - The Domestic Impact of Intra-European Social

Security. Journal of Common Market Studies, 43(5), 1027-1054. https://doi.org/doi:10.1111/j.1468-

5965.2005.00607.x 


\title{
The Europeanisation of Welfare - The Domestic Impact of Intra-European Social Security*
}

\author{
Dorte Sindbjerg Martinsen \\ Journal of Common Market Studies (2005), Vol. 43 (5), 1027-1054 \\ http://onlinelibrary.wiley.com/doi/10.1111/j.1468-
}

5965.2005.00607.x/abstract;jsessionid=D1C05EF16A7A8D49C2D04566EF9AE969.f03t04

\begin{abstract}
Studies of Europeanisation have demonstrated that the impact of European integration differs between member states and across policies. Although Europeanisation research has been expanded and clarified in recent years, we still know relatively little about the factors mediating the national processes of change that thus condition impact. This paper examines the impact of European social security integration on national welfare institutions in Denmark and Germany, and it traces the Europeanisation process, which may explain the diverging impact of a common input in the two member states. In order to understand how the same process of integration may cause diverging impact on national institutions, two sets of mediating factors are examined: 1) the institutional and de facto exposedness to European integration; and 2) the national political, administrative and legal responses to integration. It is argued that these intervening variables are decisive for how common European demands are meditated nationally and are likely to explain impact variations referring to the same cause.
\end{abstract}

\footnotetext{
* I should like to thank Martin Rhodes for his helpful comments on this paper, as well as to thank him and Gráinne de Búrca for their advice on my Ph.D. work in general. I am also very grateful for the comments from Annette Borchorst, Morten Kelstrup, Martin Marcussen, Henrik Plaschke and Marlene Wind as well as from two anonymous referees.
} 


\section{Introduction}

Studies of 'Europeanisation' have become more sophisticated in recent years, both in terms of magnitude and clarity. Having developed from a fashionable concept of divergent meaning and many faces (Olsen, 2002), it would appear as though consent has increasingly been established among scholars in recent years as concerns usage in which 'Europeanisation' concerns the effects of European integration on domestic polities, politics and policies (Featherstone, 2003, pp. 9-10; Vink, 2003).

The added value of this rather top-down conceptualisation of Europeanisation is that it is clearly distinguishable from the process of European integration and allows a more focused examination of the impact of the latter. Furthermore, such focus on impact invites scholars to explore the terrain of mediating factors contributing to varying degrees and directions of domestic change.

The spectrum of Europeanisation studies is undoubtedly broad. ${ }^{1}$ It covers the processes of change for old, new and candidate member states, and it examines the effects of European integration on a wide set of variables, including political parties, political behaviour, decision-making processes, national identities, discourses or ideas, institutions, etc. Evidently, therefore, research concerning Europeanisation requires a set of analytical choices. Furthermore, theorising on Europeanisation requires more explicit suggestions as regards the domestic conditioning of impact, i.e. the national mediating factors that are likely to account for variations in impact across member states, policies and time.

This article examines the impact of European social security integration on national welfare institutions $^{2}$ in Denmark and Germany. It also traces the Europeanisation process that may contribute to explaining the diverging impact of a common input in the two member states. In order to understand how the same process of integration may cause diverging impact on national institutions, two sets of mediating factors are examined: 1) the institutional and de facto

\footnotetext{
${ }^{1}$ For the many 'objects' of Europeanisation, see Radelli (2003, pp. 34-40).

${ }^{2}$ Institutions are the formal rules, procedures and practices, which detail and guide the principles and content of a policy. This institutional definition relies on the one given by Hall. According to Hall institutions are "...the formal rules, compliance procedures, and standard operating practices that structure the relationship between individuals in various units of the polity and economy" (Hall, 1986, p. 19).
} 
exposedness to European integration; and 2) the national political, administrative and legal responses to integration. As such 'responses' account national political processes interpreting and deciding the extent of change to meet European demands, administrative processes estimating and implementing European demands and national courts activating European rules within national court rooms or requesting the European Court to clarify EU points of law. It is argued that these intervening variables are decisive for how common European demands are meditated nationally and are likely to explain impact variations referring to the same cause. Impact then, finally, constitutes the dependent variable, and takes place when change occurs and when European demands are concretely put into effect. The effect of European integration on national welfare institutions is measurable when change takes place in national organising principles, administrative practices or legislative rules, caused by changes in EU law and/or policy.

The article is structured into five main sections: Section I presents the analytical framework for the study of welfare Europeanisation. First, the input to Europeanisation, i.e. social security integration in the European Union, is briefly identified. Secondly, the analytical choices are explained. Section II provides a more general account of 'Europeanisation', arguing that the coerciveness of European rules matters to Europeanisation, but that the manner in which European obligations are subsequently refracted through domestic mediating factors do so equally. The analysis of welfare Europeanisation in Denmark and Germany is conducted in sections III, IV and V. Section III compares the domestic exposedness to the identified integration process by outlining the principles and boundaries of the two welfare states and by depicting the de facto immigration of EU citizens to Denmark and Germany. Section IV examines welfare Europeanisation for Denmark. For the Danish case, special attention is paid to healthcare policy. Section $V$ concerns Germany. For Germany, the role of the national courts in enhancing domestic impact is examined in greater detail. Finally, some concluding remarks on the findings are provided.

\section{I: Analysing the Europeanisation of Welfare}

The present analysis of Europeanisation focuses on institutional change and investigates how the organising principles, administrative practices and legislative rules of national welfare policies may be altered as a consequence of European integration and Europeanisation. The analytical strategy draws on the insights of historical institutionalism, which, when applied to the study of 
Europeanisation, evidently suggests that institutional impact must be examined over time, as it is likely to be absent in the short term. Such impact delay is due to the fact that the meaning and scope of European integration initially must be interpreted, clarified and mediated nationally. Furthermore, as European integration is indeed dynamic but often very protracted and incremental, Europeanisation is equally so. A straightforward relationship between cause and effect is thus highly unlikely (Goetz, 2001); impact should not be expected to occur in a systematic, uniform or immediate manner.

\section{Social Security Integration in the European Union}

The European integration of social security represents the coercive rules, which in the present case constitutes the input to Europeanisation and induces change. The coordination of social security rights across the borders of member states has been regarded as a sine qua non for the free movement of workers and persons within the Community. The EU has a longstanding practice of safeguarding the social security rights of European migrants. This social protection was adopted as one of the first EEC Regulations in $1958^{3}$, amended into Regulation 1408/71 ${ }^{4}$, and has recently been substantively reformed and extended to encompass all European citizens with the adoption of Regulation $883 / 2004^{5}$. The Regulation prohibits national legislation discriminating against citizens from other member states, as it (at least partly) prohibits territorial principles formulated in national social security legislation. The Regulation prescribes that Community migrants have equal social security rights when settling in another member state as the nationals of that state, as migrants have a right to export their social security rights when deciding to reside in another member state.

The personal and material scope of the Regulation have been reformed gradually through subtle steps of integration taken in the Council of Ministers, but proposed and initiated persistently by the Commission. Furthermore, the European Court of Justice has assumed a most active role in

\footnotetext{
${ }^{3}$ Regulation 3/58, adopted by the Council on 25 September 1958.

${ }^{4}$ Regulation (EEC) No. 1408/71 of the Council of 14 June 1971 on the application of social security schemes to employed persons, to self-employed persons and to members of their families moving within the Community.

${ }^{5}$ Regulation (EC) 883/2004 of the European Parliament and of the Council of 29 April 2004 on the coordination of social security systems. Official Journal L 166, 30/04/2004 P. 0001-0123.
} 
interpreting the scope and content of cross-border welfare in the EU, and through its successive case law, it has been a significant motor of integration.

The personal scope of Regulation 1408 has undergone a gradual but continual development. From entitling only workers with proven qualifications ${ }^{6}$ to cross-border welfare, the personal scope has been incrementally expanded to the point where, by April 2004, the Regulation has been extended to all European citizens. This means that in addition to employed workers, self-employed workers, civil servants, students and pensioners, non-active persons are now also covered by the coordination rules. $^{7}$

Cross-border social security in the EU encompasses a very extensive range of material benefits. ${ }^{8}$ Over the years, the European Court of Justice and the Council of Ministers have disputed and clarified which among these included benefits are exportable. One dispute has concerned the issue of healthcare. Since 1998, the European Court of Justice has initiated the clarification of a long list of open questions concerning the relationship between the Community's fundamental free movement provisions and the territoriality of national healthcare. ${ }^{9}$ Judicial activism has clarified that the Community principles of the free movement of goods and services apply to the healthcare policy field. It has subsequently laid down that national authorisation policies ${ }^{10}$ constitute an unjustified barrier to the free movement of services for non-hospital care - also for those national systems based on benefits in kind. Regarding hospitalisation, the Court has stated that it constitutes a service within the meaning of the Treaty, but that with regards hospital care, national authorisation policies may in principle be justifiable in order to protect the stability of national

\footnotetext{
${ }^{6}$ As laid down by the Paris Treaty of 1951, article 69 and 69 (4).

${ }^{7}$ Third country nationals are covered by Council Regulation (EC) No 859/2003 of 14 May 2003, but have no right to free movement according to Community law. On the special status of third country nationals, see Roberts 2000; Martinsen 2003.

${ }^{8}$ Regulation 883/2004 has been extended to cover (a) sickness benefits; (b) maternity and equivalent paternity benefits; (c) invalidity benefits; (d) old-age benefits; (e) survivors benefits; (f) benefits in respect of accident at work and occupational diseases; (g) death grants; (h) unemployment benefits; (i) pre-retirement benefits; (j) family benefits.

${ }^{9}$ This recent cluster of case-law concerns, among other cases; Case C-120/95, 28 April 1998. Nicolas Decker; Case C158/96, 28 April 1998. Raymond Kohll; Case C-157/99, 12 July 2001. B.S.M. Geraets-Smits and H.T.M. Peerbooms; Case C-385/99, 13 May 2003. Müller-Fauré and Van Riet.

${ }^{10}$ Authorisation policies lay down that the national healthcare system only reimburses the costs of non-acute treatment carried out abroad if that treatment has been authorised beforehand.
} 
systems. However, the legal deductions of the Court have reduced the national autonomy to deny such authorisation, e.g. by laying down that authorisation must be given if the national system cannot provide care within a medically acceptable time limit.

The long history of intra-European social security and its centrality to fundamental Community principles as equal treatment and free movement mean that the input constitutes a highly institutionalised area of European integration with a strong degree of coerciveness. However, the same can certainly be said about national welfare policies built on strong historical and institutional legacies. A process of Europeanisation regarding welfare is thus assumed to be one marked by tensions and contradictions.

\section{Analytical Choices}

As the Regulation stands today, it is not least impressive for its substance and detail. Depicting the impact of all its different dimensions would exceed the scope of this article. More extensive analysis has been carried out elsewhere, in which the impact of social security integration on the national institutions of social pension, healthcare, family benefits and long-term care in Denmark and Germany has been compared in detail (Martinsen, 2004). The key findings of this analysis are described below, though in a selective manner.

The depiction of the Danish case will include the institution of social pension, but concentrate on healthcare. Social pension and healthcare have been selected, since they, as welfare institutions: i) are representative for social policy as a whole; ii) were part of the constitutive social programmes in the European welfare states; and iii) represent by far the items of greatest social expenditure. Furthermore, the traditional demarcation of healthcare within national borders is increasingly challenged by recent ECJ case-law. A more detailed examination of the Europeanisation of healthcare thus provides a present insight into how member states respond to new, but legally derived, Community obligations.

The German case demonstrates that the role of national courts is crucial to the mediation of Europeanisation and thus to the effective impact of European integration. Studies of legal integration have documented the crucial role played by the European Court of Justice in extending 
the scope and substance of Community law (Alter, 2001; Stone Sweet and Sandholtz, 1998; Stone Sweet, 2004; Weiler, 1994; 1999; Wind, 1998; 2001). My argument is that the same role must be attributed to the role of the national courts as regards impact. The extent to which national lawyers utilise Community law in national courts and the extent to which they request the European Court to clarify points of law are essential to the effective meaning and thus the impact that Community law has in individual member states. The diverging extent to which national courts try the compatibility between national and Community law is therefore likely to produce varying degrees of impact. ${ }^{11}$

Denmark and Germany have been chosen as comparative cases. These two member states represent distinct welfare traditions, for which reason their 'exposedness' to European integration must be expected to be different. They represent two contrasting forms of institutional and historical legacies, Denmark being a universalistic, residence-based welfare state, whereas Germany often represents the empirical reference point for the insurance-based, continental welfare model (Andersen, 1999; Haverland, 2003). Furthermore, they have had different 'entry points' in the Community and thus dissimilar opportunities to 'upload' their national institutional traditions, thereby reducing the adaptive pressure from European integration (Dyson and Goetz, 2003, p. 15; Börzel, 2002). It has been argued that since the Community framework coordinating social security was established by the founding fathers of the European Community, its principles were laid down in accordance with their welfare traditions. Apart from a few exceptions in individual schemes, the social security systems of the six original member states were based on the exercise of work activity and built up as Bismarckian-oriented social insurance schemes (Cornelissen, 1997, p. 35; Pieters, 1997, p. 190). It was therefore natural that 'lex loci laboris' ${ }^{12}$ became a ruling principle of the Regulation when determining the applicable legislation (Christensen and Malmstedt, 2000, p. 76). The institutionalised principles of work-based social insurance systems ensured that the migrant would not be entitled to benefits without directly having contributed to the financing of welfare schemes.

Against this historical background, scholars have argued that the core rationales of the Regulation mainly 'fit' the social insurance welfare model, and equally 'misfit' the principles of the residence-

\footnotetext{
${ }^{11}$ The varying extent to which national courts refer questions to the ECJ across policies is depicted by Stone Sweet and Brunell (2004, pp. 102-103).

${ }^{12}$ The principle prescribes that the social rights of migrants are granted according to the legislation of the state of work.
} 
based welfare model ${ }^{13}$ (Banke, 1998, p. 30; Ketscher, 1998, 2002; Abrahamson and Borchorst, 2000). The Danish welfare model should thus be more exposed to the specific process of European integration, or - put differently - be more vulnerable to its rationales and obligations.

The argument of a basic 'misfit' between institutionalised intra-European social security rights and the residence-based welfare state has been developed significantly in the Danish debate. Concretely, it has been forwarded that we face two contradictory logics when considering intra-European social security and residence-based welfare. Free movement and the right to cross-border social security are foremost compatible with an individualistic insurance principle, where there is a direct relationship between social entitlements and contributions. On the other hand, the European imperatives contradict the principles of the Danish welfare model, since it grants universal social protection on the basis of residence, without any contributory demands. Due to this fundamental 'misfit', the residence-based welfare state will gradually be forced to converge with the dominating social insurance pattern of the EU member states (Ketscher, 1998; Ketscher, 2002, pp. 221-222). In a comparative light, this hypothesis concerning convergence invites us not only to think that integration will cause harmonisation, but also that European integration has less impact on the insurance-based welfare state. As the following analysis demonstrates, such propositions, which predict impact alone on the basis of institutional 'fit'/'misfit', are at best insufficient and at worst misleading, as they do not consider other domestic factors that mediate Europeanisation.

\section{II: European Rules and the Mediating Factors of Europeanisation}

As European integration, Europeanisation denotes a process of change, which can be defined as;

“..a process of change in national institutional and policy practices that can be attributed to European integration" (Hix and Goetz, 2000, p. 27). ${ }^{14}$

\footnotetext{
${ }^{13}$ The work of Risse, Cowles and Caporaso on "Europeanisation and Domestic Change", as well as the work of Börzel, suggest that the adaptational pressure exerted by Europeanisation varies, depending on the 'goodness of fit' between a specific European integration process and the national institutions in place (Risse, Cowles and Caporaso, 2001; Börzel, 1999; Börzel and Risse, 2000). By identifying the degree of 'fit' or 'misfit', one identifies the adaptational pressure on domestic institutions that may cause change.

${ }^{14}$ This definition has been chosen on the grounds of its conciseness and applicability. For other definitions, see, among others, Börzel, 1999, p. 574; Goetz and Dyson, 2003, p. 20; Radelli, 2003, p. 30; Risse et al., 2001, p. 3.
} 
The output of European integration thus constitutes the input for the process of Europeanisation. This input is mediated nationally and becomes the output of Europeanisation. The domestic refraction of input must necessarily diversify output - not only among European policies, but also throughout member states implementing the same European policy.

As inputs to the process of Europeanisation, European rules, communications and norms clearly differ in their coerciveness and thus whether national actors are obliged to implement them, the ability to sanction non-compliance, as well as the extent to which they leave space for national actors to translate their meaning. The coerciveness of European rules and norms provides us with a sense of the impact and a formal picture of how constrained member states are (Schmidt, 2002, $\mathrm{p}$. 895). In the case of intra-European social security, member states face a highly institutionalised area, patterned by a Regulation as the key rule, which has been reformed and repeatedly simplified during its more than four decades of institutional existence. Furthermore, the European Court of Justice has clarified the content, scope and meaning of the institution. The coerciveness of the area is therefore strong. As a Regulation, its principles and rules are directly applicable and thus more capable than, for example, directives to ensure the uniformity of Community law (Hartley, 1998, pp. 196-206). However, regulations may also occasionally require amendments to national policies. Such reforms are necessary when the terms of the Regulation in question are formulated vaguely, and individual provisions must be applied in detail.

Furthermore, judicial review operating on the basis of Article 234 of the Treaty constitutes a key part of the EU's coercive rules; it is thus crucial to impact. However, academia, lawyers and administrators disagree on the multilateral effect of the Court's case law. Conant argues that member states are merely compelled to comply with individual judgements against them on the grounds that the ECJ preliminary rulings do not constitute binding precedents (Conant, 2002, pp. 63-73); however, this argument is disputable. Craig and de Búrca find that, in effect, the ECJ has established a system of multilateral effects, inviting national courts to regard previous rulings as generally binding. Contrary to Conant, they find that a previous ruling has a "multilateral and not merely a bilateral effect" (Craig and de Búrca, 1998, p. 418). The question of the bilateral versus multilateral effects of the Court's case-law has crucial bearing on the study of impact. As there is a significant cross-national variation in the extent to which national courts request the ECJ to clarify EU points of law (Stone Sweet and Brunell, 2004, p. 102-103), member states that do not have their 
laws and practices examined in relation to Community law may simply disregard the principles articulated by the ECJ. That would fundamentally question the uniform impact of Community law.

The coerciveness of European rules provides an initial notion regarding the degree and direction of EU-induced change; however, in between cause and effect, mediating factors become decisive. Such domestic conditioning variables can be divided into two, 1) exposedness or adaptive pressure and 2) national responses.

Member states are exposed to European integration in different ways and to different degrees. This exposedness is again crucial to how member states are likely to assess and respond to the perceived or de facto challenges rising from integration. ${ }^{15}$ Schmidt speaks about vulnerability (2002), Hay about exposedness (2004) and Risse, Cowles and Caporaso about adaptive pressures (2001), but their different concepts all refer to varying degrees of compatibility between supranational institutions and national ones resulting in varying degrees of adjustment pressures. The extent of exposedness or adaptive pressure is therefore not decided by supranational institutionalisation alone; rather, it is equally determined by how that process relates to established national institutions.

I argue that, in most cases, the exposedness or adaptive pressures stemming from European integration is likely to possess both institutional and de facto components. Institutional exposedness is decided by the compatibility between the legacies, rules and practices of European versus national institutions. In the case of welfare, the institutional principles of the German member state is more compatible with the obligations of Community social security policy and law than those of the Danish member state; at least from the outset; however, de facto exposedness concerns, among other factors: the factual vulnerability to European economic forces (Schmidt, 2002), the extent of transnational exchange (Stone Sweet and Brunell, 1998); or, as in the present case, de facto EUrelated immigration.

Although exposedness or adaptive pressure serves as an impetus to change, it cannot in itself predict impact (Schmidt, 2002, p. 898). National actors or organisations respond to European integration in

\footnotetext{
${ }^{15}$ See Hay (2004) for his insightful discussion of how different economies are exposed differently to globalisation. While Hay's article discusses different forms of convergence as a result of globalisation, I argue that many of its insights can be applied to the study of Europeanisation.
} 
accordance with their perception of their Community obligations, as well as how they perceive institutional and de facto exposedness.

The national contestation of European demands may be political, administrative and legal. National politicians and administrations attend to implementation, which can be defined as the way decisions are put into effect (From and Stava, 1993, p. 59; Winter 2004, p. 14). Implementation is therefore the process establishing concrete rights and obligations for those subject to law. Depending on the supranational institution in question, however, member states more or less enjoy discretion when implementing. Scholars have argued that the national transposition of Community rules constitutes a second "stronghold of national control", or the national "come-back", where member states can recodify EU decisions in closer accordance with institutional traditions, thereby clawing back some of what they may have lost through intergovernmental decision-making (Goetz, 2001, p. 217; Meny et al., 1996, p. 7; From and Stava 1993). In the short/medium term, the effect of European rights or obligations on national law and policy will remain a national decision. Political response determines whether to ignore a European requirement or how to adjust or transform national policies ensuring its compliance with supranational demands. Administrative response decides how administrative practices must be amended to comply with supranational rules. However, it is often contestable what Community law actually requires member states to do (Falkner et al., 2004, pp. 463-465), or whether domestic responses sufficiently meet the requirements. Insufficient implementation may thus represent both a deliberate act designed at protecting national institutions against perceived or de facto exposedness, or simply be due to interpretation problems. Disagreements regarding the actual meaning of Community law within and across member states are in itself likely to cause diverse impact.

Legal response constitutes the final form of contestation; it takes place in the medium/long term. As is the case with the European Court of Justice, national courts play a crucial part in integration through law. The extent to which European law is articulated in the national court room, as well as their request to the ECJ to clarify EU points of law against national law, are decisive for the practical impact that EU law attains in specific member states. Although the role of national courts has generally been neglected in both the study of European integration and Europeanisation, they are likely to explain an essential part of impact variation. National courts effectuate Community law at the national level and they may be 
“... qualified as political institutions since they are involved in the institutional interaction within the EU system. They come in at the end of the policy cycle, during the phase of implementing and controlling Community law" (Mauer et al., 2003, p. 74).

Cross-national and cross-issue variations in the extent to which EU law is invoked have not yet been researched systematically; however, suggestions have been made. Differences in reference patterns have been explained by various factors, e.g. the litigiousness of a society and transnational activity (Alter, 2000; Conant, 2001; Stone Sweet and Brunell, 1998). Other explanations could be that access to national courts differ, as does the legal tradition to refer EU points of law upwards or to integrate EU law in national legal deductions. When it comes to Denmark and Germany and the case of social security, a significant difference is that whereas Germany has social courts at the local, regional and federal levels, Denmark has no social courts; instead, Denmark has an administrative, court-like social security board of appeal ('den sociale ankestyrelse'). Furthermore, scholars suggest that Danish courts generally prefer not to involve themselves in that which they consider to be the political sphere (Mauer et al., 2003, p. 74; Laursen 2003, p. 107). Testing the plausibility of such arguments goes beyond the scope of this article, but although not knowing the precise factors determining national legal responses, the following analytical results point out that the enforcement of EU law by national courts deepens impact. Furthermore, impact is also deepened when national administrations accept the multilateral effect of litigation.

Whereas variations in impact across policies depend on the coerciveness of European rules and judicial activism, the subsequent mediation of Europeanisation within a specific field of policy thus determines the impact across member states. The argument can be summarised in the figure below: 
Figure 1: Mediating Europeanisation

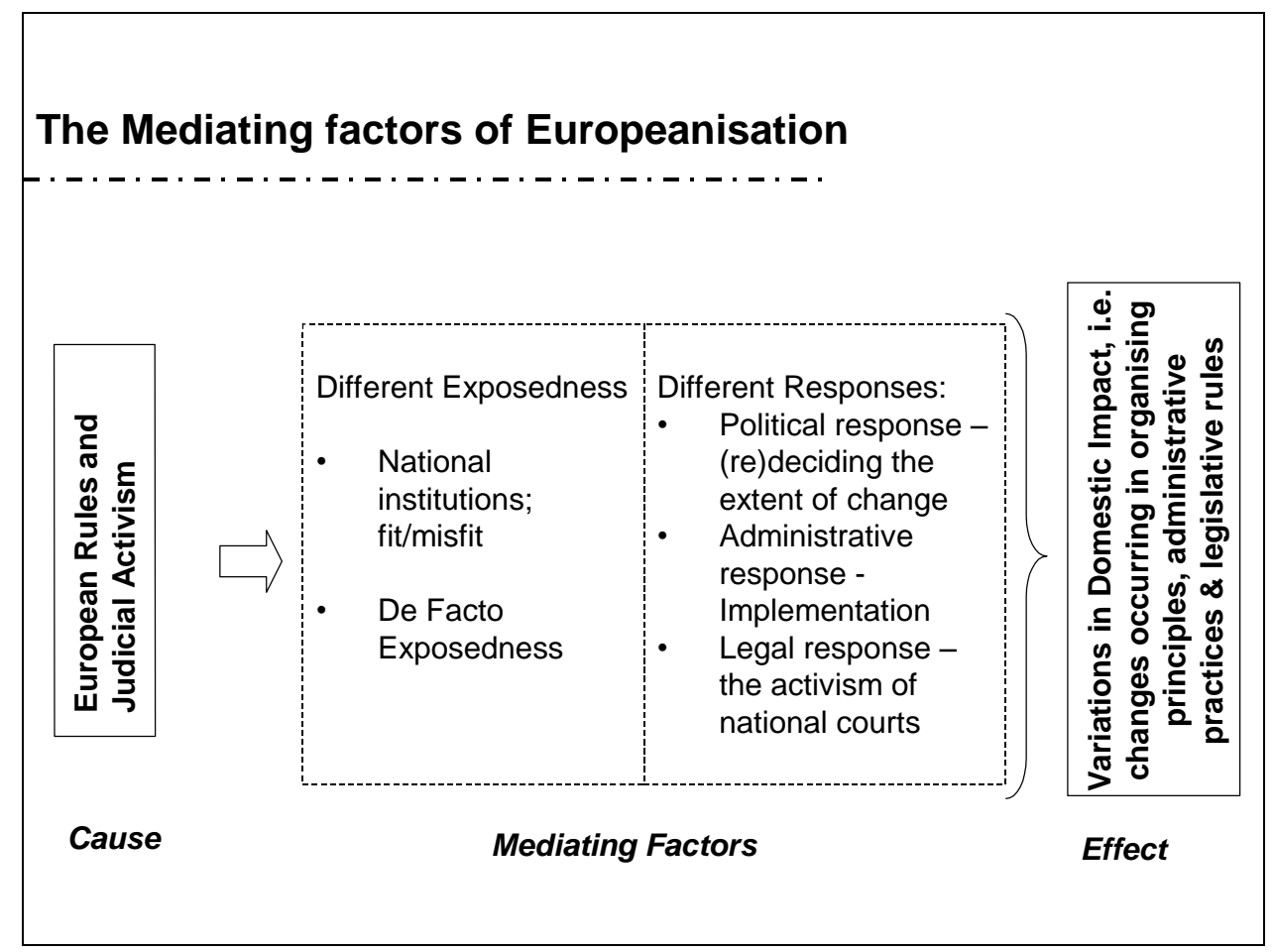

\section{III: Institutional and De Facto Exposedness}

The European integration of the free movement of workers and later persons and the associated right to access welfare regimes abroad have been monitored closely for any possible impact on national welfare policy autonomy.

The pronounced need to defend welfare autonomy has deep-rooted historical, ideological and organisational explanations, for which reason the European impact on national welfare may be especially sensitive as compared with other policy areas. The process of European integration and national welfare policies contradict one another in their historical reasoning. The institutionalisation of the modern welfare state reflects a century-long process of nationalisation and builds on a strong element of closure (Ferrera, 2003). Gradually, social security became a material right, creating ever stronger ties between the nation-state and its citizens, between national politicians and voters. From the very outset, social policies were tactically motivated by the need to create an ordered 
relationship between the nation-state and its citizens, to integrate the marginalised, and to avoid social unrest (Eichenhofer, 2000; Lidegaard, 2003). Welfare states based on residence and insurance alike have an "idea of national solidarity" embedded within them. Despite variations regarding core dimensions and in elements of interpersonal or intertemporal redistribution, it generally reflects "the core principle of social security" (Flora and Alber, 1981, p. 54).

However, the exposedness of modern welfare states goes beyond their historical reasoning; it also concerns their organising principles, contemporary boundaries and de facto vulnerability. This will be presented in the following.

\section{Organising Principles and Boundaries for Welfare}

A main characteristic of the residence-based welfare model is that social rights are granted on the basis of residence (Cornelissen, 1997, p. 32). A person is entitled to welfare because she/he is a citizen or a habitual resident, and not on the basis of contributions by her/him to any specific scheme. Most welfare benefits are universally granted. The openness of the system is therefore relatively high; it generally grants access to the entire population (Hansen, 2002, p. 9). Benefits are generally not based on contributions; instead, they are financed via taxation. The payment of taxes is, however, not a requirement for receiving a specific social benefit (Ketcher, 1998, pp. 254-255).

A main characteristic of the social insurance model is that market participation provides access to a social security scheme, and the degree thereof largely corresponds to the level of social entitlements. Persons holding employment are compulsorily insured against the risks covered by social security. The principle of lex loci laboris determines who is covered, not residence (Altmaier, 1995, p. 77). The individual earns his social rights by paying contributions (Andersen, 1999, pp. 4243). ${ }^{16}$

\footnotetext{
${ }^{16}$ Although the organising principles of the two welfare models have proven remarkable persistent, welfare reforms have blurred the distinctions in typologies, as for example illustrated by the Labour Market Fund contributions introduced in Denmark in 1994, as well as tax-financed and universally granted family benefits in Germany. Accordingly, the fit/misfit between European social security integration and national institutions are equally blurred over time.
} 
No matter how accessible welfare may be for the working or residing population, it remains a conditional and restricted right. Boundaries for welfare limit the rights to a defined set of beneficiaries, thus traditionally rendering social solidarity conditional on personal and territorial association. The formation and consolidation of modern social policies proceeded within the territorial borders of the nation-state. State formation and nation building were thus early stages of the long history of the modern welfare state that reigns today. Social policy was - and remains closely associated with the idea of the nation-state (Eichenhofer, 2001, p. 55). The welfare state inherited its sovereignty and strong emphasis on territoriality. Traditionally, the welfare state has autonomously defined who qualifies as social beneficiaries, targeting benefits to its own citizens, residents or workers. Furthermore, it has been in a sovereign position to exercise spatial control, insisting that social benefits and services are to be consumed within its own territory (Leibfried and Pierson, 1995). Social citizenship and territoriality have been the defining principles for the reach of welfare. $^{17}$

The traditional requirement for entitlement to welfare protection in Denmark has been Danish citizenship. The nationality clause is maintained in parts of the social legislation. This applies to the law on social pension, whereas for healthcare benefits, habitual residence is required. ${ }^{18}$ The postwar social security code in Germany has not drawn distinctions between Germans and foreigners, instead delineating rights through the link to the German labour market or, if unemployed, through habitual residence (Willms, 1990, p. 58; Haverkate and Huster, 1999, p. 116). The territorial principle for social policy in Germany is concretised by German law and demarcates the personal and spatial application of German social insurance. ${ }^{19}$ The principle of lex loci laboris comes before residence for German social benefits, meaning that if a person works in Germany but lives abroad, that person will remain entitled to certain social benefits in Germany (Schaaf, 1999, p. 275).

\footnotetext{
17 'Social citizenship' in the modern welfare state has, as originally conceptualised by T. H. Marshall, operated with the underlying premise of membership, as "a status bestowed on those who are full members of a community" (Marshall, 1992 (1950), p. 18).

${ }^{18}$ See Law on Social Pension $§ 2$ (Lov om Social Pension) and Laws on Health Insurance (Sygesikringsloven) § 1 and Hospital Treatment (Sygehusloven) § 5 .

${ }^{19}$ The general expression of the German principle of Lex Loci Laboris and territoriality is found in Sozialgesetzbuch IV,$\S 3$.
} 


\section{EU Immigration as de Facto Adaptive Pressure}

Eurostat data on EU-immigration to Denmark and Germany provides numerical insight concerning the number of persons from other member states that have taken up residence in these two member states between 1985 and $2000 .{ }^{20}$ The figures indicate that in absolute figures and as a percentage of the population, EU-immigration to Denmark remains comparatively low. While general intraEuropean migration between 1985 and 1998 was between 1.5\% and 1.6\% of the entire Community population, EU immigrants in Denmark merely represented $0.71 \%$ to $1.01 \%$ of the Danish population between 1985 to 2000 .

Graph 1: EU-immigration as a \% of the total population in Denmark and Germany, 1985-2000

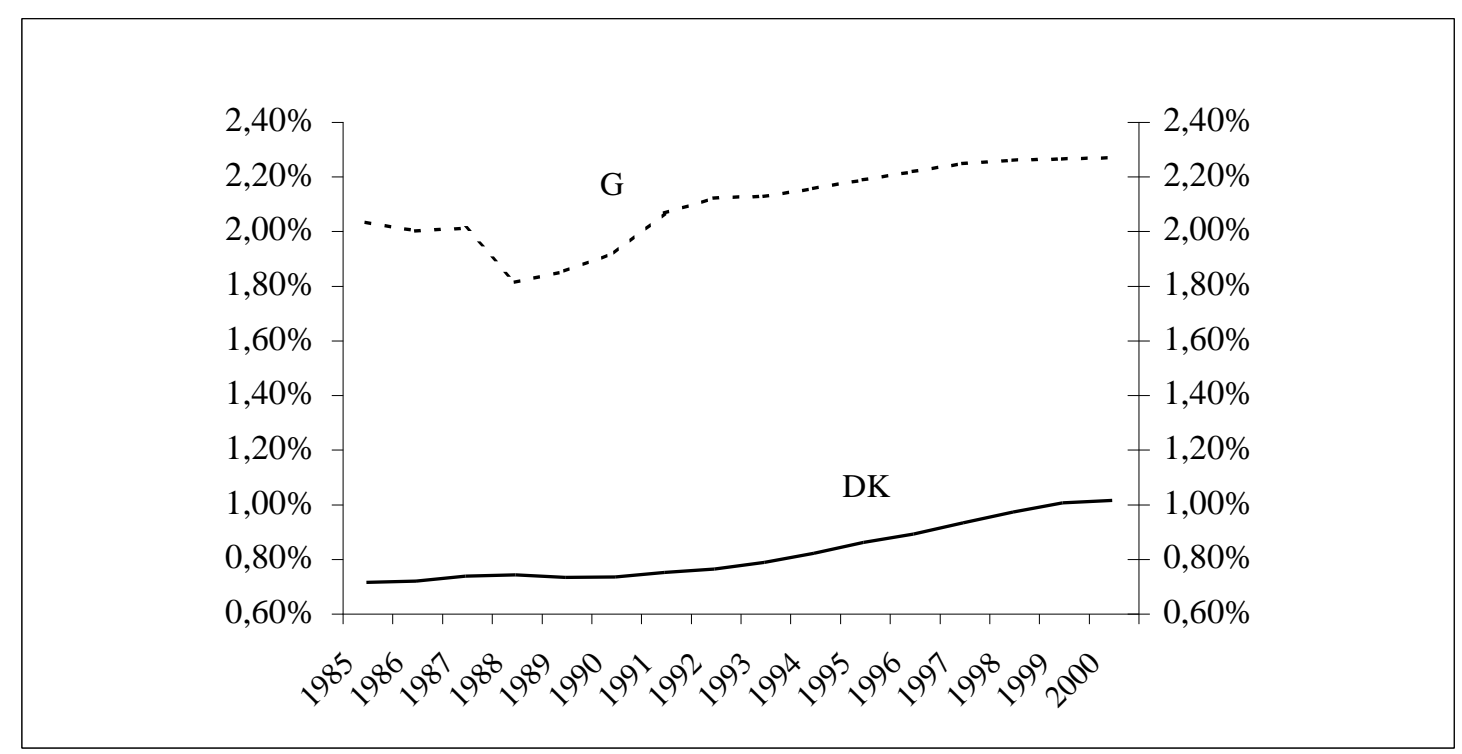

The graph above depicts relatively higher EU-immigration to Germany than to Denmark. In 1985, EU immigrants in Germany constituted $2.03 \%$ of the total German population. EU-related immigration to Germany increased to $2.26 \%$ in 2000 .

Contemporary migration figures do not support the hypothesis that the residence-based welfare state in particular should be exposed to the principle of free movement for persons. To the contrary, the data above outlines considerably higher EU-related immigration to the insurance-based welfare state than to the residence-based one. The assumption re-emphasised in the Danish debate that the residence-based welfare state faces relatively higher adaptational pressure is thus based on a rather

\footnotetext{
${ }^{20}$ See "European Social Statistics - Migration”, 2002 edition, Eurostat.
} 
static perception of institutional exposedness and on an unconfirmed notion about how EU-related immigration might develop in the future. Historical and contemporary migration figures do not confirm this dominating and surviving perception.

\section{IV: Mediating Welfare Europeanisation - the Case of Denmark}

One of the key characteristics in the Danish response towards social security integration has apparently been implementation to the letter. Denmark has had no infringement procedures enacted against it on the basis of the system coordinating social security rights. Furthermore, Denmark stands out among its counterparts for being a member state with only one preliminary reference to the European Court of Justice regarding Regulation $1408 .^{21}$

Denmark thus appears to have concentrated its efforts on the political scene, using the tool of unanimity; however, the country has subsequently accepted and implemented the political decision to the extent that no judicial epilogue has taken place. Regarding the implementation of institutionalised cross-border social security rights, Denmark lives up to its reputation as the complying member state (Rasmussen, 1988). However, adaptation has not been passive, neutral or always immediate. In its implementation of political decision-making, Denmark has amended national law both in order to meet its Community obligations as well as in order to limit its effects. Since Denmark has had only one minor preliminary ruling before the ECJ on behalf of Regulation 1408/71, its implementation of judicial decision-making exemplifies how member states other than the referring one subsequently interpret the general premises of an individual lawsuit and attests to the multilateral effect of a judgement.

When Denmark joined the European Community in 1973, it had to enact fundamental reform of its national law on social pension. Adopting the acquis communautaire on intra-European social security meant that Denmark, by the implementation of the principle of equal treatment, had to waive the Danish citizenship ('indfødsret') requirement for the personal scope of Regulation 1408/71, as well being made to allow for the exportation of social benefits (Sakslin, 2000, p. 24; Den Sociale Sikringsstyrelse 1997, hæfte 1, p. 26). Danish citizenship and residence in Denmark

\footnotetext{
${ }^{21}$ Case C-428/92, 2 June 1994. Deutsche Angestellten-Krankenkasse. The preliminary ruling addressed the application of 1408's article 93 (1).
} 
were and are the two general conditions for entitlement to pension benefits. Adopting the acquis thus meant that Denmark could no longer specifically favour its own citizens, instead having to grant equal access to its very costly social security scheme to those covered by Regulation 1408; nor could Denmark exert spatial control over the consumption of benefits. The immediate adoption of the acquis meant that both the Danish principle of social citizenship and the principle of territoriality were overruled by Community law. While Denmark initially only had to see 'social citizenship' extended to a limited range of migrant workers, the gradual extension of the Community's principle of equal treatment and the personal scope of Regulation 1408 rendered it increasingly difficult for national policy to 'favour' its nationals.

Regarding the healthcare policy field, the judicial decision-making of the European Court of Justice has also led to Danish policy reform. 28 April 1998 became the date upon which the ECJ stated its two landmark rulings, C-120/95 Decker and C-158/96 Kohll. It was also the date since which time it became irrevocably clear that the free movement principles regarding goods and services did influence the healthcare policy field. In Denmark, the judgements contradicted the Danish perception at the time that internal market rules had no impact on health benefits and services. The rulings thus raised a long line of questions regarding their scope and impact on national authorisation policies (Interview, Danish Ministry of Health, 3 April, 2001). Against this background, it was considered politically expedient to establish an interministerial working group to analyse the extent of the judgements and their eventual consequences for Danish health policy. The working group published a report ${ }^{22}$ on the consequences of the rulings, on which basis national policy was subsequently amended.

In its report, the working group admitted that the Decker/Kohll rulings implied general premises. For this reason, their scope exceeded the individual lawsuits. In this manner, Denmark admitted to its multilateral effect, meaning that the procedure entailed implications for health systems other than merely Luxembourg, and health goods and services other than just those of a pair of spectacles and dental treatment (Danish Report on the Decker/Kohll rulings 1999, p. 22). The Danish report, however, revised its interpretation of 'service'. For a service to be a service according to the meaning of the Treaty's Article 50 (ex. Article 60), there must be an element of remuneration:

\footnotetext{
${ }^{22}$ The report came out in September 1999, entitled "Consequences of The European Court of Justice rulings in the Decker/Kohll cases - statement by the working group".
} 


\begin{abstract}
"It is the view of the working group that if, on the other hand, the treatment had been taken care of by the public hospital sector, the Treaty's Article 49 would not have applied. The reason is that Article 50 defines services as services normally carried out in return for remuneration [...]Characteristic for a service is thus that a service provider offers a service in return for remuneration" (Danish Report on the Decker/Kohll rulings 1999, p. 23. Own translation, emphasis added).
\end{abstract}

The Danish (re-)interpretation of the 'service' concept meant that the vast majority of Danish healthcare services fell outside the definition, since they are provided as benefits in kind, free of charge and thus with no direct remuneration. Denmark conceded the Decker and Kohll procedure to have a discernible impact, but the national definition of what constituted a service within the meaning of the Treaty allowed for the exception of the entire public hospital sector, as well as all types of non-hospital care provided free of charge.

However, the interpretations of the working group marked a decisive break with the traditional national reasoning, namely in admitting that the internal market principles - under certain conditions - applied equally to healthcare services. This decisive break meant that health services for which the insured personally paid one part and the competent institution the other were judged to fall under the service concept of the EC Treaty. The conclusions in the report led to a policyreform, which went into effect 1 July 2000 and allowed certain services to be purchased abroad with subsequent fixed reimbursement from the relevant Danish institutions. The policy-reform allowed general and specialist medical treatment and dental assistance for persons insured under group $2^{23}$, physiotherapy, and chiropractic treatments to be purchased abroad. ${ }^{24}$

In the subsequent case, C-157/99 Geraets-Smits and Peerbooms, the European Court went one decisive step further in clarifying the applicability of the internal market rules to healthcare policies. Denmark was among the intervening governments to deliver an opinion in the case. The Danish opinion restated the conclusions of the Decker/Kohll report (Interview, Danish Ministry of Health, 3 April 2001). The argument forwarded was that due to the absence of remuneration, hospital

\footnotetext{
${ }^{23}$ Denmark has two categories of health coverage. The insured person chooses if he wants to belong to Group 1, under which he is entitled to free medical care, but only from the assigned doctor or from a specialist assigned by the generalist. If the person wants to belong to Group 2, he chooses doctor and specialist freely, but has to pay a part of the costs himself. Group 1 is the most popular choice. Only about $1.6 \%$ of all Danish residents are insured under Group 2 (Interview, the Danish Ministry of Health, 3 April 2001; Danish Report on the Decker/Kohll cases 1999, p. 37).

${ }^{24}$ The policy reform entered into force by law no. 467 of 31 May 2000 and BEK no. 536 of 15 June 2000.
} 
treatment did not constitute a service within the meaning of the Treaty's Article 50 (Report for the Hearing, pp. 76-77). Beyond making this point, Denmark argued that another precondition for a service to be Treaty-related was that the service provider must do so with a view to making a profit (Report for the Hearing, p. 78).

The Court, however, overturned these national assessments and stretched the notion of 'remuneration' in the Treaty's Article 50 so as also to cover indirect payments such as those transferred by social security funds to cover healthcare costs (Hatzopoulos, 2002, p. 693). On the basis of this partially revised definition of services, most healthcare services, including hospital care provided free of charge, came to constitute services within the meaning of the Treaty. In the same ruling, however, the Court ruled that national authorisation policies might be justified under certain circumstances. The individual lawsuit of Geraets-Smits and Peerbooms was therefore not likely to require any immediate amendments to national legislation.

The ruling has, however, had an indirect impact on Danish policy. Since 1 July 2002, Danish patients have had a right to treatment outside the contracted public hospitals in the event these cannot provide the necessary treatment within two months. The intention of this policy reform was to bring down waiting lists and ensure the patient a certain freedom of choice if the public health supply was insufficient. This health policy reform represented an institutionalisation of an obligation to refer patients to non-contracted healthcare providers in the event that public care could not be provided within the specified time limit. However, the freedom to reform national health policy had been restricted beforehand by the ECJ judicial ruling in Geraets-Smits and Peerbooms, where the Court clarified that the principle of non-discrimination means that once a treatment cannot be provided by the contracted national provider, the member state must not favour a nationally established, non-contracted, i.e. private, provider over a provider in another member state. In the remarks proposing the national policy reform, its relation to EC-law stood clear:

The European Court of Justice has in a judgement dated 12 July 2001 (C-157/99) taken a stand on certain EU judicial questions regarding hospital treatment. The Court has stated that hospitalisation is part of the EC-Treaty's provisions on free movement of services. The need of planning and cost-containment can, however, justify certain restrictions in access to treatment paid by the public health service or health insurance. Such rules shall, however, be objective, proportional and non-discriminatory. Supposedly, that implies that when access to publicly paid treatment is given to 'independent' hospitals outside public control and planning, as is the case in the present legislative proposal, there has to be given access on an equal footing with hospitals in other EU member states. 
The legislative proposal is in conformity herewith (Legislative proposal L 64, proposed 29 January 2002. Adopted 19 March 2002. Own translation.).

Furthermore, impact from the later Müller-Fauré and Van Riet judgement ought to be expected. The Court's reasoning in this later litigation responds to some of the aspects of national confusion and questions raised in the wake of the Decker/Kohll procedure, the national policy reform in this regard, and the Smits-Peerbooms ruling. With the cluster of judgements regarding national health service and Community law, it can be provisionally concluded that:

- The fundamental principle of freedom to provide services applies to all healthcare systems, including those based on benefits in kind. The Danish residence-based, public healthcare system, providing benefits in kind and financed by taxes is thus not exempted from the Court's conclusions.

- There need not be an element of remuneration or profit for a service to be a healthcare service within the meaning of the Treaty. It is thus clear that the restrictive application of the Decker/Kohll procedure, as laid down in the Danish report and the subsequent policy reform, is no longer in line with Community obligations.

- The Decker/Kohll procedure generally applies to non-hospital provision of healthcare.

\section{V: Mediating Welfare Europeanisation - the Case of Germany}

When comparing the Danish and German responses, it is clear that the two countries contrast most markedly in terms of their record of referring preliminary questions to the European Court of Justice. In contrast to Denmark, German national courts have tested and questioned the scope and content of Regulation 1408/71 by preliminary references, and thus on occasion been forced to admit rights due to a direct legal injunction.

The German response in the political arena is also dissimilar from the Danish case. Germany has generally been in favour of further integration and supported the Commission's proposals to extend the personal and material scope of the Regulation. The German government thus supported the extension of the regulatory scope to third country nationals and non-actives (Interviews, Deutsche Verbindungsstelle, 18 September 2001; German Federal Ministry for Labour and Social Affairs, 17 September 2001). On the other hand, the German government denied that the Decker/Kohll caselaw had any consequence for the German health insurance system and national authorisation 
policies on the grounds that the decisions only applied to healthcare systems reimbursing the costs of treatment $^{25}$ (BMG Pressemitteilung, 5 June 1998; Berg, 1999; Mrozynski, 1999; Kötter, 2000). This national re-interpretation of the case-law premises contrasts sharply with the Danish interpretation. The discrepancy between the German interpretation and the evolved Community law becomes even starker when one considers the later clarifications laid down in the cases of GeraetsSmits and Peerbooms and Müller-Fauré and Van Riet.

The German preliminary reference record tells us that litigants, German lawyers and German courts have continuously questioned the extent to which Germany complies with its intra-European social security obligations. In total, there have been 338 judgements between 1971 and 2002 in which reference was made to Regulation $1408 .^{26}$ Of these 338 judgements, 85 were preliminary references by German national courts, and one judgement was an infringement procedure against Germany. $25 \%$ of all of the case-law regarding Regulation 1408/71 concerned Germany. Germany thus holds the second largest number of preliminary references and infringement procedures of all member states between 1971 and 2002 and is outdone only by Belgium, with 32.5\%.

German national courts have taken a most active part in questioning and enhancing the scope, impact and effectiveness of EC law. Over the three decades in which Regulation 1408 has been in force, German national courts have persistently questioned the scope and content of the Regulation, as well as the consistency between national policies and European obligations, as Graph 2 illustrates below:

\footnotetext{
${ }^{25}$ As do Luxembourg, Belgium and France.

${ }^{26}$ I.e., according to a CELEX based analysis of preliminary references and infringement procedures on the basis of Regulation 1408/71 between 1971-2002. The analysis shows significant variations in the number of cases raised against the individual member states. See Martinsen, 2004.
} 


\section{Graph 2: German References and Infringements Referring to Regulation 1408/71}

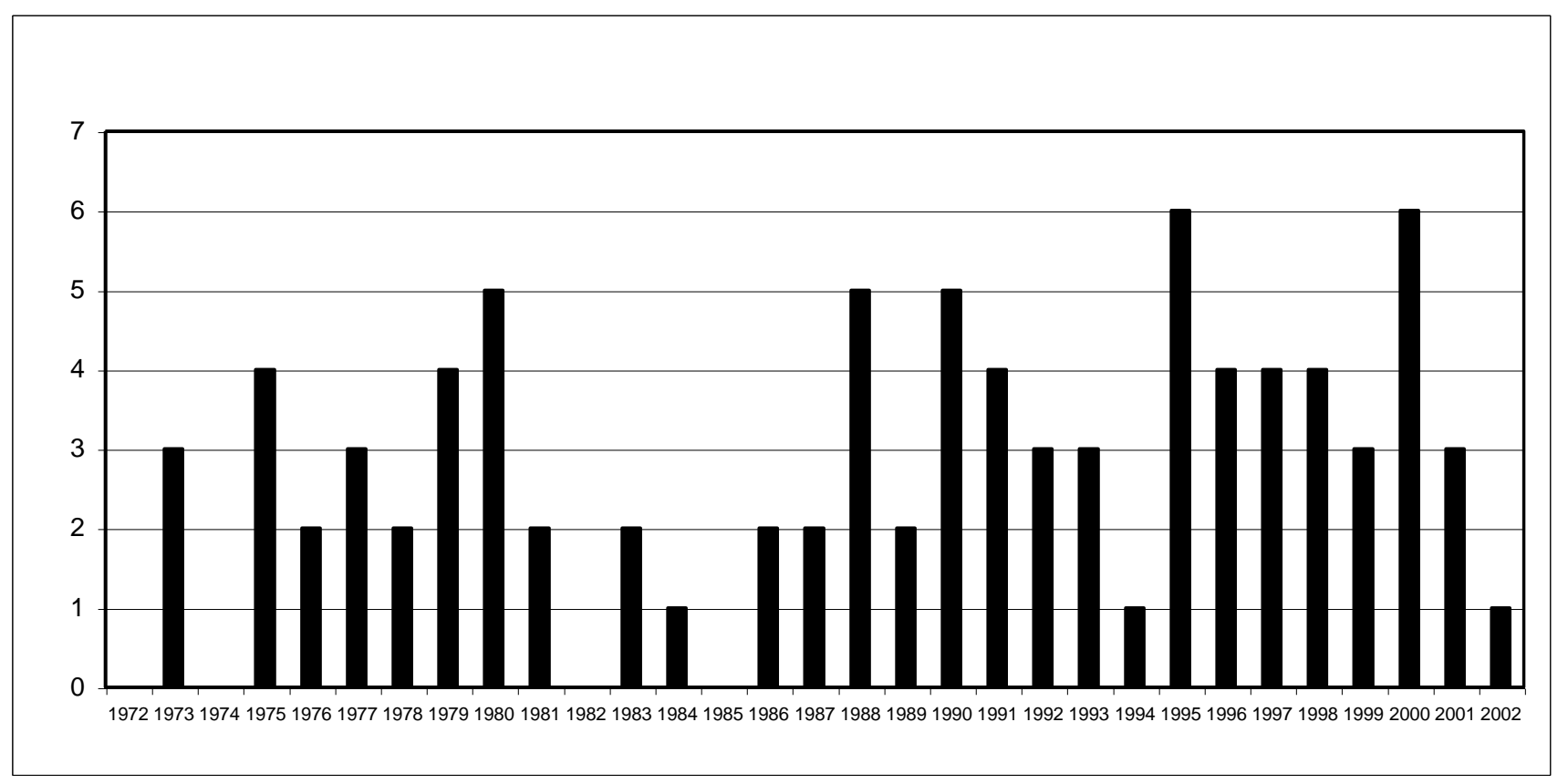

The German preliminary reference record regarding Regulation 1408/71 refutes the notion that Germany, due to its 'fit' between contribution-based social insurance and the logic of Regulation 1408, should have had "fewer conflicts with European obligations related to social security", as suggested by Conant (2001, pp. 112-113). To the contrary, the activism of German national courts has extended the specific impact of Regulation 1408 on German welfare institutions. Due to legal response as one domestic factor conditioning the extent of Europeanisation, the domestic impact has been relatively stronger on the insurance-based welfare state in comparison to its residence-based counterpart.

Litigation against Germany includes some of the most important cases in the history of the European coordination of social security rights, such as C-10/90 Masgio $^{27}$, C-45/90 Paletta ${ }^{28}$, C245/94 and C-312/94 Hoever and Zachow ${ }^{29}$, C-131/96 Romero ${ }^{30}$, C-160/96 Molenaar ${ }^{31}$, C-85/96

\footnotetext{
${ }^{27}$ Case C-10/90, 7 March 1991. Maria Masgio.

${ }^{28}$ Case C-45/90, June 1992. Brennet $A G$.

${ }^{29}$ Joined cases C-245/94 and C-312/94, 10 October 1996. Ingrid Hoever and Iris Zachow.

${ }^{30}$ Case C-131/96, 25 June 1997. Carlos Mora Romero.
} 
Sala $^{32}$. The Community Court decided all of these cases in favour of the migrant, and some of the cases questioned fundamental aspects of German law and its organising principles. Moreover, these cases enhanced the general scope of intra-European social security law. The ECJ's social security litigation against Germany therefore likewise refutes the restated theoretical assumption that the Court ought to act cautiously in relation to the more powerful member states or when strong national preferences, as those stated in submitted opinions to the ECJ, are adversely affected by a decision (Garrett, 1992; Garrett, 1995; Garrett, Keleman and Schultz, 1998). In social security matters, the Court has overtly decided against the submitted opinions of the member states in general and certainly against the more powerful among them.

Thus the case-law of the Court has directly influenced the organising principles of German welfare institutions. In the case of Paletta, the Court overruled the German government's position that a migrant worker and his family falling ill outside of German territory were not entitled to German cash sickness benefits, even though the German employer seriously disputed the evidence that the migrant worker and his entire family were in fact sick. In the combined cases of Hoever and Zachow, the Court ruled that the German 'child-raising allowance' constituted a family benefit within the meaning of Regulation 1408/71 and that family members of the migrant worker were equally entitled to the benefit. Furthermore, the Court overruled the national principle of territoriality, thereby extending the benefit beyond German borders. The case of Sala likewise addressed the German child-raising allowance. Here, the Court decided that an EU citizen, lawfully residing in another member state, can rely on the Treaty's equal treatment provision in all situations covered by the material scope of Community law (O'Leary, 1999, p. 74; Langer, 2000, p. 46). The Court overruled the condition as formulated in German law that only foreigners with a German residence permit are entitled to child-raising allowance. In the case of Molenaar, the Court again ruled the German principle of territoriality to be at odds with Community law. The Molenaar case concerned the German benefit for long-term care. According to German law, the benefit could only be paid out to beneficiaries residing in Germany; nevertheless, the Court set aside the national residence clause and concluded that as a benefit in cash, German long-term care was exportable to other member states. The Court overruled that the national benefit constituted a 'benefit-in-kind substitute', a 'Sachleistung Surrogat', as held by the German government, and thus found the

\footnotetext{
${ }^{31}$ Case C-160/96, 5 March 1998. Manfred Molenaar and Barbara Fath-Molenaar.

${ }^{32}$ Case C-85/96, 12 May 1998. Maria Martinez Sala.
} 
territorial limitation of the benefit contrary to Community law (Haverkate and Huster, 1999; Zuleeg 1998).

In several cases, the ECJ has overruled the territoriality of the insurance-based welfare state and challenged conditions formulated in national law defining who has, and under what conditions, a right to German welfare. Over the decades, the impact of Community law has become much more prominent in national policies. When national policies have been constructed so as to evade Community obligations, the national courts and the European Court have subsequently brought it into line. While the individual member state continues to possess the competence to formulate national welfare policies, it is increasingly clear that the obligation to do so in line with Community law indeed constitutes the boundary of welfare autonomy.

\section{Concluding Remarks}

The findings of this article demonstrate that the European integration of social security rights has considerable impact on both the institutions of the residence-based and the insurance-based welfare state. European integration has from the very outset - as well as through its dynamic evolution compromised social sovereignty. The demarcation of welfare is no longer a national decision; rather, European rules laying down who is entitled to welfare benefits and settling the spatial reach of welfare consumption take precedence over conflicting national legislation and policy. As a result of the fundamental principles of free movement in the EU, the Europeanisation of welfare has taken place.

However, Europeanisation and impact vary in the respective member states. Despite the fact that the institutional exposedness is stronger for the residence-based welfare state due to a constitutive 'misfit' between the principles of European and national rules, the direction of change is not towards harmonisation or convergence.

First, because the member state in the North has attracted considerably fewer EU immigrants as a percentage of the population than its continental counterpart. Apparently, it takes more than universal and residence-based welfare to attract European migrants. One explanation is that, at least 
until the 2004 enlargement of the Union and the adopted restrictions on immigration from the new member states, the German labour market was more open and more attractive to 'outsiders'.

Secondly, the national responses have been decisive for effective impact. National responses refract the meaning of European demands in a manner so that impact occurs, but not uniformly, systematically or immediately. Political responses determine the extent of change. Denmark responded when implementing the acquis, not by transforming its scheme on social pension into a work-related one, but instead by adapting it to 'fit' its Community obligation, meanwhile maintaining institutional traditions. Years of residence became the earning criteria. The principle of social citizenship was compromised, but not eroded.

Different administrative responses equally mediate the impact of European integration. The fact that Denmark chose to reform healthcare policy as a consequence of the ECJ case-law gives the appearance that it initially anticipated its Community obligations prior to the multilateral effect of jurisprudence even having been confirmed. The relatively prompt response is, however, more likely to be a deliberate strategy aimed at avoiding further interference. As the precise meaning and general impact of judicial decision-making in initial cases are often unclear, the Danish strategy appears to have been that it is better to define than to be defined. As such, Denmark succeeded in limiting the impact of the Decker and Kohll procedure to an autonomously defined set of healthcare benefits. Denmark thus managed to mobilise a certain degree of 'pro-activism' in the reactive phase of decision-making.

The German strategy appears to be more confrontational. At least in the short/medium term, nonimplementation neutralises impact. Such a strategy may in part explain the judicial activism of German courts. Their role becomes to invoke rights that are not ensured through political and administrative responses. However, de facto EU-related immigration to Germany is also likely to partially explain the higher reference rate to the ECJ. With more European migrants inhabiting German territory, the reach and content of their EU-ensured rights are likely to be tested and invoked in the national legal setting to a greater extent. However, the fact that Germany has social courts while Denmark does not is yet another source of explanation for the contrasting usage of European social law and dissimilar reference records. The accessibility of national courts and the 
tradition of national lawyers to integrate Community law as 'the law of the land' are other legal societal factors important for the effective reach and impact of European rules.

Together, these mediating factors determine the course and extent of Europeanisation. The study of impact and the domestic conditioning thereof confirms that there is no straightforward connection between cause and effect (Goetz, 2001). In the short to medium term, these findings essentially question the uniformity of European law. However, in the long term, and as the effectiveness and scope of a specific set of European rules increase, a more uniform implementation of European obligations must be expected. For the policy field of welfare, it remains clear that the days are over where social security was 'an island beyond the reach' ${ }^{33}$ of Community law - and that that applies equally across the welfare models of Europe, irrespective of their distinct characteristics.

\section{Correspondance:}

Dorte Sindbjerg Martinsen

Department of Political Science

University of Copenhagen

Øster Farimagsgade 5

DK - 1014 København K

Tel: +4535323426 Fax: +4535323399

E-mail: $\underline{\text { dm@ifs.ku.dk }}$

\footnotetext{
${ }^{33}$ As formulated by Advocate General Tesauro in the cases of Decker and Kohll.
} 


\section{References}

Abrahamson, P. and Borchorst, A. (2000) 'Penge er ikke alt - Om EU og den Danske Velfærdsstat'. In Dosenrode, S. (ed.) Danmark og ØMU’en - Politiske Aspekter (Århus: Systime).

Alter, K. (2000) 'The European Union's Legal System and Domestic Policy: Spillover or Backlash ?'. International Organizations, Vol. 54, No. 3, pp. 489-518.

Alter, K. (2001) Establishing the Supremacy of European Law. The Making of an International Rule of Law in Europe (Oxford University Press).

Altmaier, P. (1995) ‘Europäisches koordinerende Sozialrecht - Ende des Territorialitätsprinzip?’. In Eichenhofer, E. and Zuleeg, M. (Hrsg.) Die Rechtsprechung des Europäischen Gerichtshofs zum Arbeits- und Sozialrecht im Streit (Köln: Bundesanzeiger Verlagsges. MbH), pp. 71-93.

Andersen, J. G. (1999) 'Den universelle velfærdsstat er under pres - men hvad er universalisme?'. Grus, Vol. 56/57, pp. 40-63.

Banke, A. (1998) 'Administration af 1408/71 - Problemer og mulige løsninger'. In Greve, B. (ed.) EU og den frie bevagelighed. Forskningsrapport nr. 4/1998 (Roskilde University), pp. 27-35.

Berg, W. (1999) 'Grenzüberschreitende Krenkenversicherung in der EU - Auswirkungen der Urteile EuGH, EuZW 1998, 345-Kohll, und EuGH, EuZW 1998, 343-Decker auf das deutsche Gesundheitswesen'. Europäische Zeitschrift für Wirtschaftrecht, heft 19, pp. 587-591.

Börzel, T. (1999) 'Towards Convergence in Europe? Institutional Adaptation to Europeanisation in Germany and Spain'. Journal of Common Market Studies, Vol. 37, No. 4, pp. 573-596.

Börzel, T. and Risse, T. (2000) 'When Europe Hits Home: Europeanization and Domestic Change'. EUI Working Paper 2000/56, pp. 1-26.

Christensen, A. and Malmstedt, M. (2000) 'Lex Loci Laboris versus Lex Loci Domicilii - an Inquiry into the Normative Foundations of European Social Security Law'. European Journal of Social Security, Vol. 2, No. 1, pp. 69-111.

Conant, L. (2001) 'Europeanization and the Courts: Variable Patterns of Adaptation among National Judiciaries'. In Cowles, M.G., Caposaso, J., and Risse, T. (eds) Transforming Europe - Europeanization and Domestic Change” (Ithaca and London: Cornell University press), pp. 97-116.

Conant, L. (2002) Justice Contained - Law and Politics in the European Union (Ithaca and London: Cornell University Press). 
Cornelissen, R. (1997) '25 Years of Regulation (EEC) No. 1408/71 - Its Achievements and its Limits'. In 25 Years of Regulation (EEC) no. 1408/71 on Social Security for Migrant Workers - Past Experiences, Present Problems and Future Perspectives, report from the European Conference on Social Security (Stockholm: Swedish National Social Insurance Board), pp. $27-68$.

Craig, P. and de Búrca, G. (1998) EU Law - Text, Cases and Materials (Oxford University Press). Den Sociale Sikringsstyrelse (1997) Hafte 1: Generel introduktion - Lovvalgsregler - Vejledning af april 1997 om EF-regler om social sikring (Copenhagen: Den Sociale Sikringsstyrelse).

Dimitrova, A. and Steunenberg, B. (2000) 'The Search for Convergence of National Policies in the European Union: An Impossible Quest?'. European Union Politics, Vol. 1, No. 2, June, pp. 201-227.

Dyson, K. and Goetz, K. (2003) 'Living with Europe: Power, Constraints, and Contestation'. In Dyson, K., and Goetz, K. (eds) Germany, Europe and the Politics of Constraints (Oxford University Press), pp. 3-37.

Eichenhofer, E. (2000) 'Die Sozialversicherung - Hinterlassenschaft Bismarcks'. In Eichenhofer, E. (Hrsg.) Bismarck, die Sozialversicherung und deren Zukunft (Berlin: Arno Spitz GmbH), pp. $15-43$.

Eichenhofer, E. (2001) Sozialrecht der Europäischen Union (Berlin: Erich Schmidt Verlag GmbH and Co.).

Eurostat (2002) European Social Statistics - Migration.

Everson, M. (1995) 'The Legacy of the Market Citizen'. In Shaw, J., and More, G. (eds) New Legal Dynamics of European Union (Oxford: Clarendon Press), pp. 73-90.

Falkner, G, Hartlapp, M., Leiber, S. and Treib, O. (2004) 'Non-Compliance with EU Directives in the Member States: Opposition through the Backdoor?'. West European Politics, Vol. 27, No. 3, pp. 452-473.

Featherstone, K. (2003) 'Introduction: In the Name of Europe'. In Featherstone, K., and Radaelli, C. (eds) The Politics of Europeanization (Oxford University Press), pp. 3-27.

Ferrera, M. (2003) 'European Integration and National Social Citizenship: Changing Boundaries, New Structuring ?'. Comparative Political Studies, Vol. 36, No. 6, pp. 611-652.

Flora, P. and Alber, J. (1981) 'Modernization, Democratization, and the Development of Welfare States in Western Europe'. In Flora, P., and Heidenheimer, A.J. (eds) The Development of Welfare States in Europe and America (New Brunswick: Transaction Books), pp. 37-80. 
From, J. and Stava, P. (1993) 'Implementation of Community Law: The Last Stronghold of National Control?'. In Andersen, S.S., and Eliassen, K.A. (eds) Making Policy in Europe The Europeification of National Policy-making” (London: Sage Publications), pp. 55-67.

Garrett, G. (1992) 'International Cooperation and Institutional Choice: The European Community's Internal Market'. International Organization, Vol. 46, No. 2, spring, pp. 533-560.

Garrett, G. (1995) 'The Politics of Legal Integration in the European Union'. International Organization, Vol. 49, No. 1, winter, pp. 171-181.

Garrett, G., Kelemen, R.D. and Schultz, H. (1998) 'The European Court of Justice, National Governments, and Legal Integration in the European Union'. International Organisations, Vol. 52, No. 1, pp. 149-176.

Goetz, K.H. (2001) 'European Integration and National Executives: A Cause in the Search of an Effect'. In Goetz, K.H., and Hix, S. (eds) Europeanised Politics. European Integration and National Political Systems (London: Frank Cass), pp. 211-231.

Hall, P.A. (1986) Governing the Economy: The Politics of State Intervention in Britain and France (Cambridge: Polity Press).

Hansen, H. (2002) Elements of Social Security (Copenhagen: The Danish National Institute of Social Research).

Hartley, T. (1998) The Foundation of European Community Law (Oxford Clarendon Press).

Hatzopoulos, (2002) 'Killing National Health and Insurance Systems but Healing Patients? The European Market for Health Care Services after the Judgments of the ECJ in Vanbraekel and Peerbooms'. Common Market Law Review, Vol. 39, pp. 683-729.

Haverkate, G. and Huster, S. (1999) Europäisches Sozialrecht (Baden-Baden: Nomos Verlagsgesellschaft).

Haverland, M. (2003) 'Social Policy: Transforming Pension, Challenging Health Care?'. In Dyson, K., and Goetz, K. (eds) Germany, Europe and the Politics of Constraints (Oxford University Press), pp. 271-289.

Hay, C. (2004) 'Common Trajectories, Variable Paces, Divergent Outcomes? Models of European Capitalism under Conditions of Complex Economic Interdependence'. Review of International Political Economy, Vol. 11, No. 2, pp. 231-262.

Hix, S. and Goetz, K. H. (2000) 'Introduction: European Integration and National Political Systems'. West European Politics, Vol. 23, No. 4, pp. 1-27. 
Holloway, J. (1981) Social Policy Harmonisation in the European Community (Westmead: Gower Publishing Company Limited).

Ketscher, K. (1998) Socialret - Almindelige Principper. Retssikkerhed og Administration (Copenhagen: GadJura).

Ketscher, K. (2002) Socialret - Almindelige Principper. Retssikkerhed og Administration. Grundvardier (Copenhagen: GadJura).

Kötter, U. (2000) 'Marktsteuerung im Gesundheitswesen und europäische Markt- und Wettbewerbsordnung'. Sozialer Fortschritt, 49. Jahrgang, Heft 2/3, pp. 27-31.

Langer, R. (2000) 'Artikel 39-42 EGV'. In Fuchs, M. (Hrsg.) Kommentar zum Europäischen Sozialrecht (Baden-Baden: Nomos Verlagsgesellschaft), pp. 37-60.

Laursen, F. (2003) 'Denmark: in Pursuit of Influence and Legitimacy'. In Wessels, W., Maurer, A., and Mittag, J. (eds) Fifteen into One? The European Union and its Member States (Manchester University Press), pp. 92-115.

Leibfried, S. and Pierson, P. (1995) 'Semisovereign Welfare States: Social Policy in a Multitiered Europe'. In Leibfried, S. and Pierson, P. (eds) European Social Policy - Between Fragmentation and Integration (Washington, D.C.: The Brookings Institution), pp. 43-77.

Lidegaard, B. (2003) 'Velfærdsstaten som Dansk Overlevelsesstrategi'. In Petersen, K. (ed.) 13 Historier om den Danske Velfardsstat (Odense: Syddansk Universitetsforlag), pp. 149-159.

Marshall, T.H. (1992) Citizenship and Social Class and other essays (Cambridge: Cambridge University Press).

Martinsen, D.S. (2003) 'Who has the Right to Intra European Social Security? From Market Citizens to European Citizens and Beyond'. EUI Working Paper, Department of Law 2003/13, pp. 1-48 (October 2003).

Martinsen, D.S. (2004) European Institutionalisation of Social Security Rights: A Two-layered Process of Integration. PhD Thesis, European University Institute, pp. 1-392.

Mauer, A., Mittag, J. and Wessels, W. (2003) 'National Systems' Adaptation to the EU System: Trends, Offers, and Constraints'. In Koehler-Koch, B. (ed.) Linking EU and National Governance (Oxford University Press), pp. 53-82.

Meny, Y., Muller, P. and Quermonne, J-L. (1996) 'Introduction'. In Mény, Y., Muller, P. and Quermonne, J-L. (eds) Adjusting to Europe (London: Routledge), pp. 1-25.

Mrozynski, P. (1999) 'Der Einfluss des Wettbewerbs- und Vergaberechts in Europa auf die Erbringung von Sozialleistungen'. Sozialer Fortschritt, 9/99, pp. 221-228. 
O’Leary, S. (1999) 'European Communities and EEA - Putting Flesh on the Bones of European Union Citizenship'. European Law Review, Vol. 24, pp. 68-79.

Olsen, J. (2002) 'The Many Faces of Europeanization'. Journal of Common Market Studies, Vol. 40, No. 5, pp. 921-952.

Pieters, D. (1997) 'Towards a Radical Simplification of the Social Security Co-ordination'. In Schoukens, P. (ed.) Prospects of Social Security Co-ordination (Leuven: Uitgeverij Acco), pp. 117- 225.

Radelli, C.M. (2003) 'The Europeanization of Public Policy'. In Featherstone, K., and Radaelli, C. (eds) The Politics of Europeanization (Oxford University Press), pp. 27-57.

Rasmussen, H. (1988) 'Denmark'. In Siedentopf, H. and Ziller, J. (eds) Making European Policies Work - The Implementation of Community Legislation in the Member States (Sage Publications), pp. 91-162.

Risse, T., Cowles, M.G. and Caporaso, J. (2001) 'Europeanization and Domestic Change: Introduction'. In Cowles, M.G., Caposaso, J. and Risse, T. (eds) Transforming Europe Europeanization and Domestic Change (Ithaca and London: Cornell University press), pp. 121.

Roberts, S. (2000) “"Our view has not changed" the UK's response to the proposal to extend the coordination of social security to third country nationals'. European Journal of Social Security, Vol. 2, No. 2, pp. 189-204.

Sakslin, M. (2000) National Report: Denmark (Brussels: European Observatory on Social Security for Migrant Workers), pp. 1-60.

Schaaf, M. (1999) "Die Urteile des EuGH zur Leistungsgewährung in der GKV - Gefahr für die deutsche Gesundheitspolitik ?”. Die Sozialgerichtbarkeit, Vol. 6/99, pp. 274-282.

Schmidt, V.A. (2002) 'Europeanization and the Mechanisms of Economic Policy Adjustment'. Journal of European Public Policy, Vol. 9, No. 6, pp. 894-912.

Stone Sweet, A. and Sandholtz, W. (1998) 'Integration, Supranational Governance, and the Institutionalization of the European Polity'. In Sweet, A.S. and Sandholtz, W. (eds) European Integration and Supranational Governance (Oxford: Oxford University Press), pp. 1-27.

Stone Sweet, A. (2004) The Judicial Construction of Europe (Oxford University Press).

Stone Sweet, A. and Brunell, T. (1998) 'Constructing a Supranational Constitution: Dispute Resolution and Governance in the European Community'. The American Political Science Review, Vol. 92, No. 1, pp. 63-81. 
Stone Sweet, A. and Brunell, T. (2004) 'Constructing a Supranational Constitution'. In Stone Sweet, A. (ed.) The Judicial Construction of Europe (Oxford University Press), pp. 45-109.

Vink, M. (2003) 'What is Europeanisation and other Questions on a New Research Agenda'. European Consortium for Political Research, Vol. 3, No. 1, http://www.essex.ac.uk/ecpr/publications/eps/onlineissues/autumn2003/resear ch/vink.htm

Weiler, J. (1994) ‘A Quiet Revolution - The European Court of Justice and Its Interlocutors'. Comparative Political Studies, Vol. 26, No. 4, January, pp. 510-534.

Weiler, J. (1999) The Constitution of Europe: Do the new clothes have an emperor? and other essays on European Integration (Cambridge: Cambridge University Press).

Willms, B. (1990) Soziale Sicherung durch Europäische Integration, Auswirkungen des Gemeinschaftsrechts auf Ansprüche gegen deutsche Sozialleistungsträger, (Baden-Baden: Nomos Verlagsgesellschaft).

Wind, M. (1998) IR Theory Meets European Union Law; Constitutional Battles, Sovereign Choices \& Institutional Contingencies in the Legacy of the European Integration Process. PhD Thesis. European University Institute, Florence.

Wind, M. (2001) Sovereignty and European Integration - Towards a Post-Hobbesian Order (London and New York: Palgrave).

Winter, S. (2004) Implementering og Effektivitet (Aarhus: Systime).

Zuleeg, M. (1998) 'Die Einwirkung des Europäischen Gemeinschaftsrechts auf die deutsche Pflegeversicherung'. In Sieveking, K. (Hrsg.) Soziale Sicherung bei Pflegebedürftigkeit in der Europäischen Union (Baden-Baden: Nomos Verlagsgesellschaft), pp. 159-179. 